\title{
Bibliometric trends of South African environmental health articles between 1998 and 2015: Making local research visible and retrievable
}

\author{
C Y Wright, ${ }^{1,2} \mathrm{PhD}$; F Dominick, ${ }^{3}$ BSc; Z Kunene, ${ }^{1}$ BCur Hons; T Kapwata, ${ }^{1}$ MSc; R A Street,${ }^{1,4} \mathrm{PhD}$ \\ ${ }^{1}$ Environment and Health Research Unit, South African Medical Research Council, Pretoria, South Africa \\ ${ }^{2}$ Department of Geography, Geoinformatics and Meteorology, Faculty of Natural and Agricultural Sciences, University of Pretoria, South Africa \\ ${ }^{3}$ Ludwig Maximilian University of Munich, Germany \\ ${ }^{4}$ Discipline of Occupational and Environmental Health, School of Nursing and Public Health, College of Health Sciences, University of KwaZulu- \\ Natal, Durban, South Africa
}

Corresponding author: CY Wright (cwright@mrc.ac.za)

\begin{abstract}
Background. South Africa (SA) has to grapple with multiple burdens of disease for which environmental factors have a role to play in both causation and prevention. This article describes a bibliometric review of environmental health indexed literature for SA over an 18-year period. Objectives. To provide an overview of the nature of SA-based published environmental health indexed research and to identify search challenges, frequently researched topics, and gaps and opportunities for future research.

Methods. The Web of Science, PubMed and Science Direct were used to search for original, peer-reviewed and review articles with the inclusion criteria 'environmental health' and 'South Africa' available online and published between 1998 and 2015, inclusively.

Results. A total of 230 journal articles were included in the bibliometric analysis. The highest number of articles $(n=54)$ was published in 2015. The majority of the first authors were affiliated with SA institutions $(n=160,69.5 \%)$. For the articles where funding was explicitly declared $(n=148)$, the three most frequently occurring agencies that funded the published research were the National Research Foundation in SA ( $n=17)$, the South African Medical Research Council $(n=13)$ and the Water Research Commission $(n=9)$. There was little inter-annual/ environmental health category variation over time owing to the relatively small sample size. The largest number of retrieved journal articles was in the area of environmental pollution control $(n=76)$, followed by environmental health lifestyle and behaviour-related topics $(n=42)$ and then water monitoring $(n=26)$.

Conclusions. Despite the research needed to solve large environmental health challenges in SA, environmental health was only used as a keyword in title, author keywords or abstract for 230 SA-based studies over an 18-year period. This makes it extremely difficult for environmental health research to be located and used to inform the profession as well as the research agenda. Several issues that environmental health practitioners are typically tasked to implement and monitor are not indexed as environmental health topics. The need for authors to use 'environmental health' as a keyword is emphasised, particularly if research is to inform decision-making and policy support, as well as guide future research in the country.
\end{abstract}

S Afr Med J 2017;107(10):915-924. DOI:10.7196/SAMJ.2017.v107i10.12429

Worldwide, an estimated 12.6 million deaths each year are attributed to an unhealthy environment. ${ }^{[1]}$ Environmental risk factors (unsafe water, inadequate sanitation and hygiene, indoor air pollution from solid fuel use, urban outdoor air pollution, and lead exposure) were associated with $5 \%$ of all deaths in South Africa (SA) in 2000. The joint attributable burden was high in children aged $\leq 5$ years, with nearly $11 \%$ of total deaths in this age group. ${ }^{[2]}$ Many of these deaths could be prevented by appropriate public health interventions.

Despite the pressing environmental health problems in SA, no research has assessed the bibliometric characteristics of environmental health research in the country. Such studies have been done for other sciences ${ }^{[3]}$ and for a specific topic ${ }^{[4]}$ or disease, ${ }^{[5]}$ but not for environmental health research as a whole in SA. A bibliometric assessment provides patterns of publications within a field of study or body of literature. It can help decipher overall patterns in research, indicate where and how to find the articles, and provide direction for future research. The World Health Organization defines environmental health as those aspects of human health and disease that are determined by factors in the environment. It also refers to the theory and practice of assessing and controlling factors in the environment that can potentially affect health. ${ }^{[6]}$

\section{Objectives}

To provide an overview of the nature of published SA environmental health indexed research over an 18-year period and to identify search challenges, frequently researched topics, and gaps and opportunities for future research.

\section{Methods}

Search procedures

We used an adapted version of the bibliometric analysis methodology applied by Pouris and Pouris ${ }^{[4]}$ and Chuang et al. ${ }^{[3]}$ The literature search was conducted in March 2016 in three electronic databases: the Institute for Scientific Information (ISI) Web of Science Citation Index Expanded (SCI-Expanded), the US National Library of Medicine/National Institutes of Health PubMed (https://www.ncbi. nlm.nih.gov/pubmed/), and Science Direct (www.sciencedirect. com). The search for published articles was limited to between the 
years 1998 and 2015, inclusively. Search terms were 'environmental health' (the Medical Subject Headings (MeSH)) exact thesaurus term match for environmental health ${ }^{[7]}$ ) AND 'South Africa'. In Web of Science, limits were set for the search in all databases for article, other and review, in Science Direct, restrictions were set in journals for article, review article, short survey and discussion, and in PubMed, limits were set for the time period and for all fields and types of articles.

\section{Inclusion criteria}

Full-text articles that met inclusion criteria similar to those used by Chuang et al. ${ }^{[3]}$ available online through an open-access platform or via two of the authors' institutional libraries, were included in the dataset for review (Table 1). Both search terms needed to appear in the title or author keywords or abstract. First the article title, then the abstract of the article and the aim/hypothesis/objective(s) in the introduction were reviewed to determine relevance to the topic 'environmental health' and 'South Africa'. In addition, the article had to focus on an SA issue or an SA study site. The article was excluded if the study was only done by an SA institution and not at an SA study site. Review articles were included. For cross-checking purposes, an independent double check was made by two different researchers regarding whether or not to include an article in the study. Where the researchers did not agree, two additional researchers reviewed the article and a final decision was made whether to include or exclude the article based on the defined inclusion criteria.

\section{Article processing and categorisation}

Bibliometric characteristics of all retrieved articles were downloaded into a Microsoft Excel spreadsheet (Microsoft Office Professional Plus 2013, Microsoft, USA), and each article was given a unique identity number. Downloaded information, as suggested by Carpenter et al. ${ }^{[8]}$ included names of authors, title of article, year of publication, name of the journal in which the article was published, and, in accordance with the visibility metric applied by similar bibliometric studies in South Africa, ${ }^{[4,9]}$ its 2016 ISI impact factor (extracted from the Journal Citation Reports Journal 2016 Impact Factor List), affiliation of first author, country of first author, and whether the article was a research article or a review. The articles were also allocated to one of the environmental health subcategories based on the scope of practice of environmental health practitioners in $\mathrm{SA}^{[10]}$ (Table 2). A brief description of each subcategory is provided to illustrate the complexity of subcategories in this field of public health. We used these categories rather than the ISI Web of Science subject categories ${ }^{[3]}$ because in SA environmental health research aims to serve the profession and the country, as well as contribute to international knowledge.

Four subcategories emerged during the article processing stage, namely lifestyle/behaviour, climate change, sustainable development and occupational health. The latter is probably an erroneous finding (occurring where occupational health and environmental health were mentioned), but we have included it for illustration purposes, and this will be explained in the discussion.

For completeness, an independent double allocation to the subcategories by two different researchers was conducted in April 2016. Again, when the two researchers did not agree on an article's topic allocation, the same two additional researchers who had already reviewed several articles for the final decision whether to include or exclude the article based on the defined inclusion criteria also reviewed the article for the appropriate category. Finally, a decision was made on the journal article's appropriate category.

\section{Data processing and statistical analysis}

After processing and categorisation, the articles spreadsheet was prepared for export into Stata 14 (StataCorp, USA) for further analysis. Descriptive statistics were explored regarding individual variables and relations between several variables. Variables included number of articles published per year, journal names and number of articles per journal, number of different main-author countries, number of articles per category of environmental health research, and number of review articles v. research articles. Comparisons of bibliometric characteristics are discussed and interpreted as numbers and percentages.

\section{Results}

\section{Bibliometric description of the sample}

A total of 1182 articles were retrieved. After removing all duplicates ( $n=99)$, there were 1083 articles remaining for critical review. These articles were scrutinised and 853 were excluded after reading the title, abstract, aim, hypothesis and objectives in the introduction showed that the focus of the article was not in fact environmental health related to an SA-specific (in-country) issue or an SA study site. The total number of articles remaining was 230 (Appendix 1).

The number of published articles by year and cumulatively during the 10 -year period is shown in Fig. 1. No more than 30 relevant articles were retrieved per year, except for 2015. The highest number of retrieved articles was published in $2015(n=54)$, followed by 2014 with 28 articles published. Of the total, $79.0 \%$ of retrieved articles were original research articles and the remaining 49 were review articles.

Ninety-one different institutions, including national and international institutions, were represented in the sample of first authors' first reported affiliation. The majority of the retrieved articles' first authors were affiliated with SA institutions $(n=160$, $69.5 \%)$. The highest-numbering first author's first affiliation was the University of Cape Town $(n=50)$, followed by the University of KwaZulu-Natal $(n=31)$, the South African Medical Research Council (SAMRC) ( $n=14)$ and Tshwane University of Technology $(n=15)$. Across all years, the province with the most articles was the Western Cape $(n=51)$, followed by Gauteng $(n=49)$.

The USA was the country with the greatest number of first authors after SA, followed by the UK. Only three other sub-Saharan

Table 1. Four study inclusion criteria and their descriptions

\begin{tabular}{ll}
\hline Inclusion criterion & Description \\
\hline 1. Keywords & Returned from search for 'Environmental health' and 'South Africa' \\
& $\begin{array}{l}\text { Evident in the title, author keywords or abstract } \\
1998-2015, \text { inclusive }\end{array}$ \\
$\begin{array}{ll}\text { 2. Date range } & \text { Full article available online (free to download or through authors' institutional library where not } \\
\text { open access) }\end{array}$ \\
$\begin{array}{ll}\text { 3. Availability } & \text { South African } \\
\text { 4. Study site } & \begin{array}{l}\text { Note: Keywords could appear in the title or abstract or as keywords of the article. We also checked the aim, hypothesis and objectives in the introduction for clarification when it was not clear } \\
\text { whether or not the article met the inclusion criteria. }\end{array}\end{array}$
\end{tabular}




\section{Table 2. Classification subcategories for SA-focused environmental health research articles*}

\begin{tabular}{|c|c|c|c|}
\hline No. & Categories & Brief subcategory description $^{\dagger}$ & $\begin{array}{l}\text { Articles }(N=230) \text {, } \\
n(\%)\end{array}$ \\
\hline 7 & $\begin{array}{l}\text { Environmental } \\
\text { pollution control }\end{array}$ & $\begin{array}{l}\text { Ensuring hygienic working, living and recreational environments } \\
\text { Identifying the polluting agents and sources of water, air and soil pollution } \\
\text { Taking the required preventive measures to ensure that the general environment is free } \\
\text { from health risks }\end{array}$ & $76(33.0)$ \\
\hline 15 & Lifestyle, behaviour & $\begin{array}{l}\text { Environmental factors influencing lifestyle diseases, e.g. tobacco, alcohol, physical activity, } \\
\text { sun exposure }\end{array}$ & $42(18.2)$ \\
\hline 1 & Water monitoring & $\begin{array}{l}\text { Monitoring and sampling of water intended for use for human consumption and for } \\
\text { recreational and commercial use } \\
\text { Monitoring of surface waters for waterborne diseases } \\
\text { Ensuring the monitoring of effective waste water treatment and water pollution control, } \\
\text { including the collection, treatment and safe disposal of sewage and other water-borne } \\
\text { waste, and surveillance of the quality of surface water and ground water }\end{array}$ & $26(11.3)$ \\
\hline 2 & Food control & $\begin{array}{l}\text { Informal and formal sectors are monitored to ensure the safe handling of foodstuffs } \\
\text { during their production, storage and delivery } \\
\text { Licensing of food premises, condemnation of unsafe foods and ensuring the sale and } \\
\text { supply of safe meat and milk }\end{array}$ & $21(9.0)$ \\
\hline 4 & $\begin{array}{l}\text { Health surveillance of } \\
\text { premises }\end{array}$ & $\begin{array}{l}\text { Residential, business and public premises are regularly monitored to identify, monitor and } \\
\text { evaluate health risks and hazards and institute remedial and preventive measures } \\
\text { Ensuring the abatement and prevention of any condition on any premises that is likely to } \\
\text { constitute a nuisance or health hazard }\end{array}$ & $17(7.3)$ \\
\hline 3 & $\begin{array}{l}\text { Waste management and } \\
\text { hygiene monitoring }\end{array}$ & $\begin{array}{l}\text { Ensuring the proper refuse storage, collection, transportation, transfer and processing, } \\
\text { materials recovery and final disposal } \\
\text { Ensuring proper management of liquid waste, including sewage and industrial effluents }\end{array}$ & $10(4.3)$ \\
\hline 14 & $\begin{array}{l}\text { Control and monitoring } \\
\text { of hazardous substances }\end{array}$ & Ensuring correct labelling and registration of hazardous substances & $7(3.0)$ \\
\hline 5 & $\begin{array}{l}\text { Surveillance and } \\
\text { prevention of } \\
\text { communicable diseases }\end{array}$ & $\begin{array}{l}\text { Investigating environmental factors relating to the spread of notifiable infectious diseases } \\
\text { and putting measures in place to prevent the spread thereof } \\
\text { Implementation of education, health and hygiene promotion programmes }\end{array}$ & $6(2.6)$ \\
\hline 6 & $\begin{array}{l}\text { Vector control } \\
\text { monitoring }\end{array}$ & $\begin{array}{l}\text { Eradication and identification of vectors and their habitats and breeding places } \\
\text { Conducting vector control in the interests of public health, including control of } \\
\text { arthropods, molluscs, rodents and other alternative hosts of diseases }\end{array}$ & $6(2.6)$ \\
\hline 13 & Malaria control & $\begin{array}{l}\text { Implementation of a malaria control and surveillance programme } \\
\text { Conducting continued health education and awareness programmes on malaria }\end{array}$ & $6(2.6)$ \\
\hline 19 & Sustainable development & $\begin{array}{l}\text { Environmental health and sustainable development, i.e. living conditions, financial and } \\
\text { economic cost-benefit analysis }\end{array}$ & $6(2.6)$ \\
\hline 9 & Chemical safety & $\begin{array}{l}\text { Permitting, licensing and auditing premises that deal with chemicals } \\
\text { Facilitating advice, education and training on pesticides and chemical safety }\end{array}$ & $4(1.7)$ \\
\hline 17 & Climate change & Decadal effects of climate on environmental health risk factors and outcomes & $2(0.8)$ \\
\hline 20 & Occupational health & $\begin{array}{l}\text { Deals with the prevention and treatment of job-related injuries and illnesses. Includes all } \\
\text { aspects of health and safety in the workplace, including environmental factors }\end{array}$ & $1(0.4)$ \\
\hline 11 & $\begin{array}{l}\text { Radiation (ionising } \\
\text { and non-ionising) } \\
\text { monitoring and control }\end{array}$ & $\begin{array}{l}\text { Ensuring that ionising and non-ionising radiation sources are registered with the } \\
\text { Department of Health and meet licence conditions } \\
\text { Monitoring safe transportation of radioactive material to ensure compliance } \\
\text { Ensuring that radioactive sources are registered and all radiation waste materials from } \\
\text { hospitals are properly disposed } \\
\text { Ensuring protection against any form or source of electromagnetic radiation }\end{array}$ & $1(0.4)$ \\
\hline 12 & Port health & $\begin{array}{l}\text { Monitoring, inspecting, sampling and labelling all imported foodstuffs, cosmetics and } \\
\text { disinfectants at all ports of entry } \\
\text { Sampling foodstuffs on aeroplanes and ships }\end{array}$ & $1(0.4)$ \\
\hline 10 & Noise control & Controlling and preventing vibration and noise pollution & 0 \\
\hline 8 & Disposal of the dead & $\begin{array}{l}\text { Controlling, restricting or prohibiting the business of an undertaker or embalmer, } \\
\text { mortuaries and other places or facilities for the storage of dead bodies }\end{array}$ & 0 \\
\hline
\end{tabular}

African countries were represented by first authors, namely Tanzania, Zimbabwe and Egypt (Table 3). The London School of Hygiene and
Tropical Medicine was the non-SA first author main affiliation with the highest number of retrieved articles $(n=4)$ in the study. 


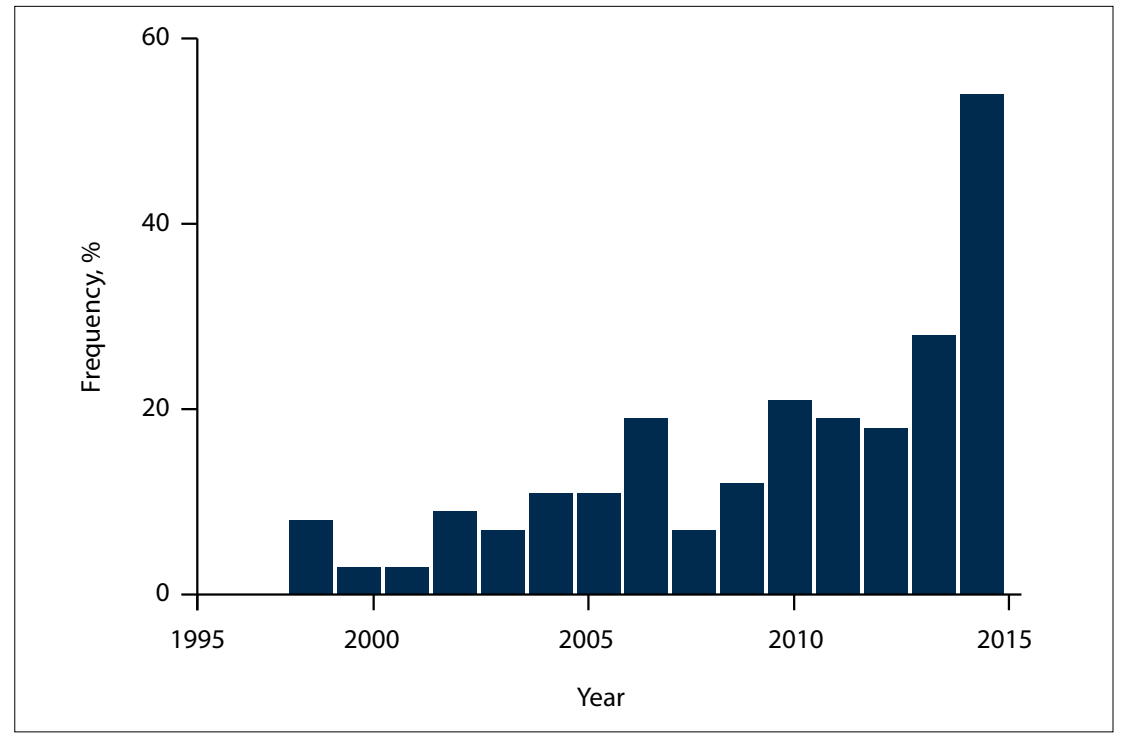

Fig. 1. Frequency of published articles by year over the period of study from 1998 to 2015.

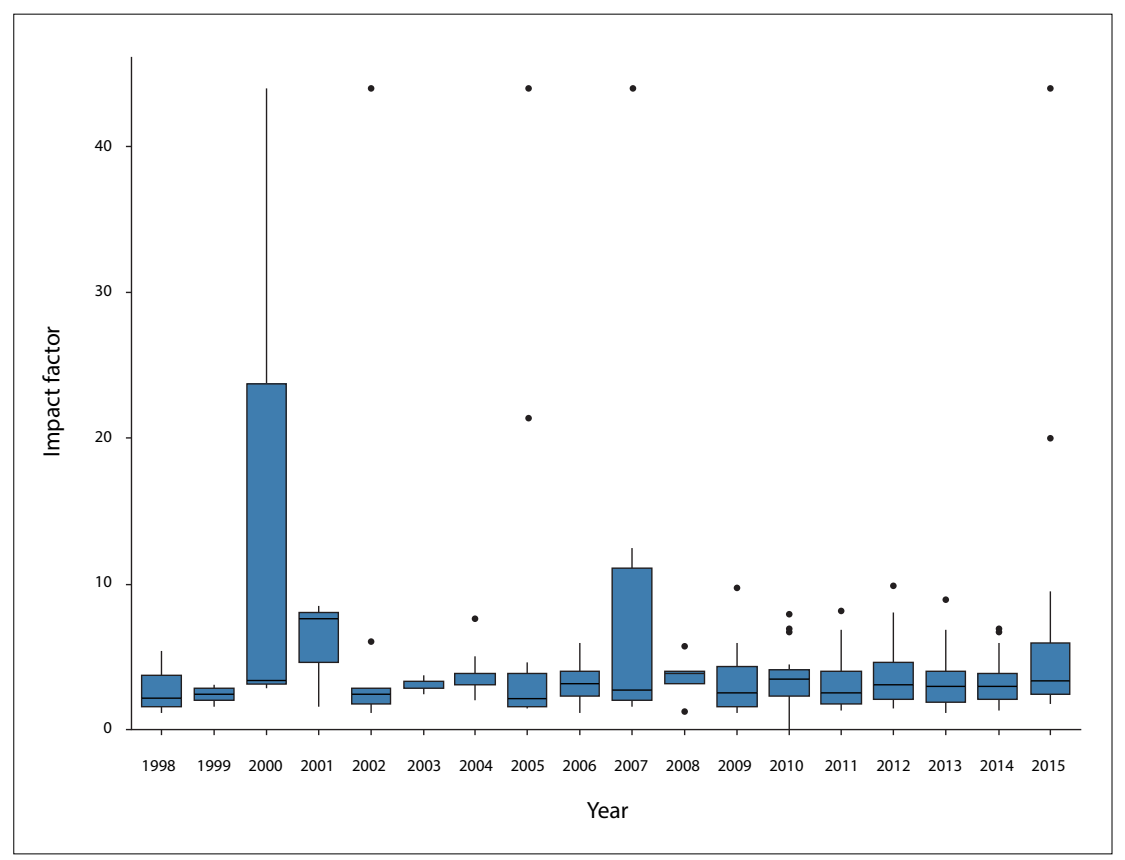

Fig. 2. Impact factors of the journals in which the retrieved articles were published, by year of publication from 1998 to 2015. The five anomalies are five articles published in The Lancet (2016 impact factor 44.002).

The 230 retrieved articles included in the study were published in 130 different journal titles. The journal with the most retrieved articles was Environmental Research $(n=10)$, followed by NeuroToxicology ( $n=9)$, Environment International $(n=7)$, The Lancet $(n=6)$ and Science of the Total Environment $(n=6)$. The Thomson Reuters 2016 impact factors of the journals ranged from 1.06 (Journal of Occupational and Environmental Hygiene) to 44.00 (The Lancet) (Fig. 2). The majority $(n=185,80.4 \%)$ of the journals had an impact factor of $<4$ and only 9 had impact factors of $>10$.
For the retrieved articles where funding was explicitly mentioned $(n=148)$, the three most frequently mentioned agencies were the National Research Foundation in SA $(n=17)$, the SAMRC $(n=13)$ and the Water Research Commission ( $n=9)$.

Fig. 3 provides a description of the impact factors of the 230 articles by nationality. There was a smaller number of non-SA first authors $(n=67)$ compared with SA first authors $(n=163)$. However, the articles published by non-SA first authors were generally published in journals with higher impact factors.
Table 3. Number of retrieved articles according to country of first author affiliation between 1998 and 2015

\begin{tabular}{ll}
\hline Country & $\begin{array}{l}\text { Frequency, } \\
\boldsymbol{n}(\%)\end{array}$ \\
\hline Australia & $4(1.7)$ \\
Bulgaria & $1(0.4)$ \\
Canada & $3(1.3)$ \\
China & $2(0.8)$ \\
Denmark & $1(0.4)$ \\
Egypt & $1(0.4)$ \\
France & $2(0.8)$ \\
Jamaica & $1(0.4)$ \\
Japan & $1(0.4)$ \\
Netherlands & $2(0.8)$ \\
Norway & $2(0.8)$ \\
Portugal & $1(0.4)$ \\
South Africa & $160(69.5)$ \\
Sweden & $2(0.8)$ \\
Switzerland & $5(2.1)$ \\
Tanzania & $1(0.4)$ \\
UK & $15(6.5)$ \\
USA & $25(10.8)$ \\
Zimbabwe & $1(0.4)$ \\
Total & $230(100)$ \\
&
\end{tabular}

\section{Number of retrieved articles by environmental health sub- categories}

The review and analysis of the retrieved articles were based on the subcategories for environmental health as defined in the Scope of Practice for Environmental Health Practitioners ${ }^{[10]}$ practising in SA. Fig. 4 is a count of the total number of publications in each of the 20 categories. Table 2 (righthand column) shows that the largest number of retrieved journal articles was in the area of environmental pollution control $(n=76$, $33.0 \%$ ), followed by the newly defined subcategory of lifestyle and behaviourrelated topics ( $n=42,18.2 \%)$, and then water monitoring $(n=26,11.3 \%)$. There was no trend in the pattern of article frequency within these (or any of the other) environmental health subcategories by year, except perhaps for a slight step change between 2009 and 2010 for articles retrieved and categorised in the lifestyle and behaviour category. Environmental pollution control (category 7) and lifestyle/behaviour (category 15) had the highest number of publications for the period 1998 - 2010 (Fig. 5).

\section{Statistical analysis}

Linear regression was run to assess the relationship between time (1998 - 2015) and the number of publications over that period. There was a strong positive correlation that 


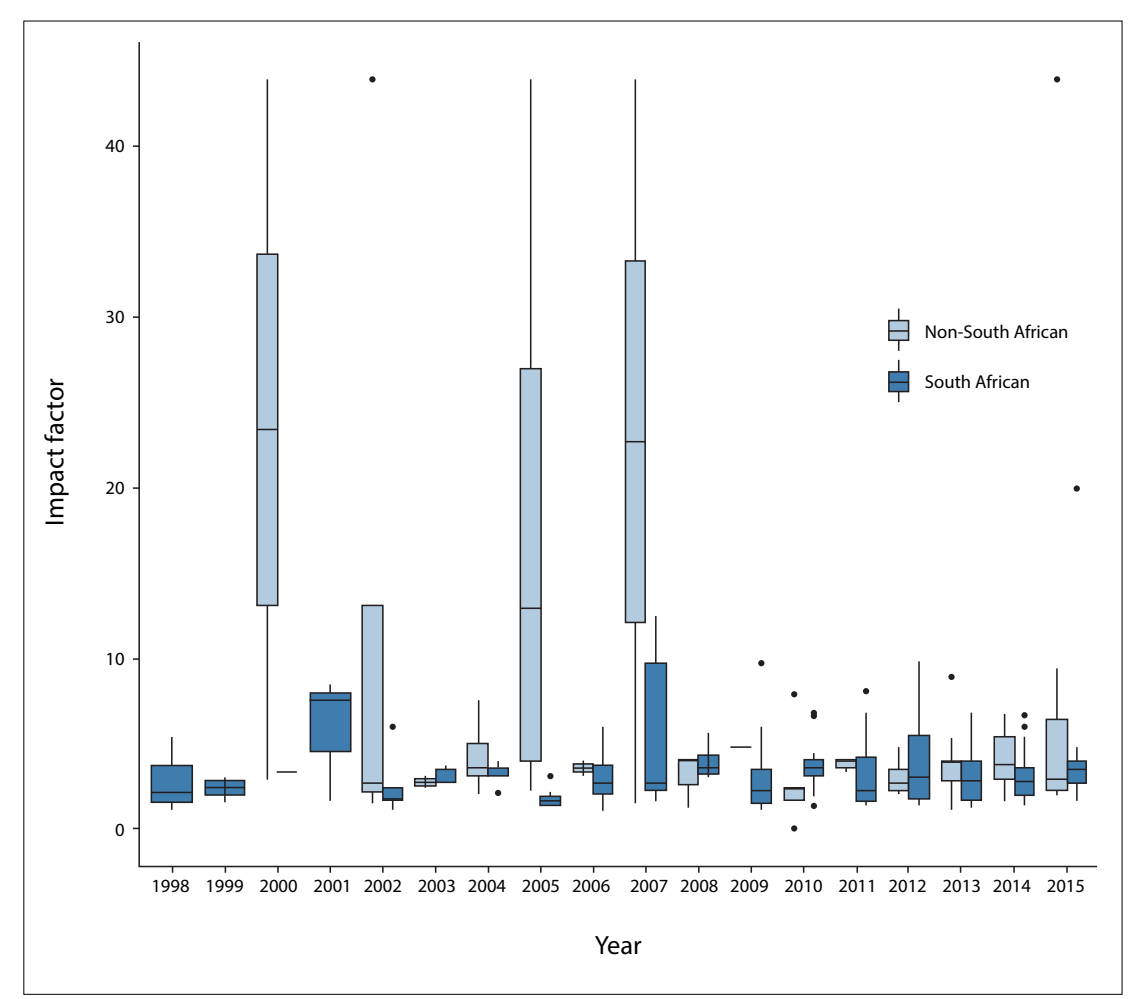

Fig. 3. Number of retrieved articles for the top four most frequently occurring environmental health categories by year from 1998 to 2015.

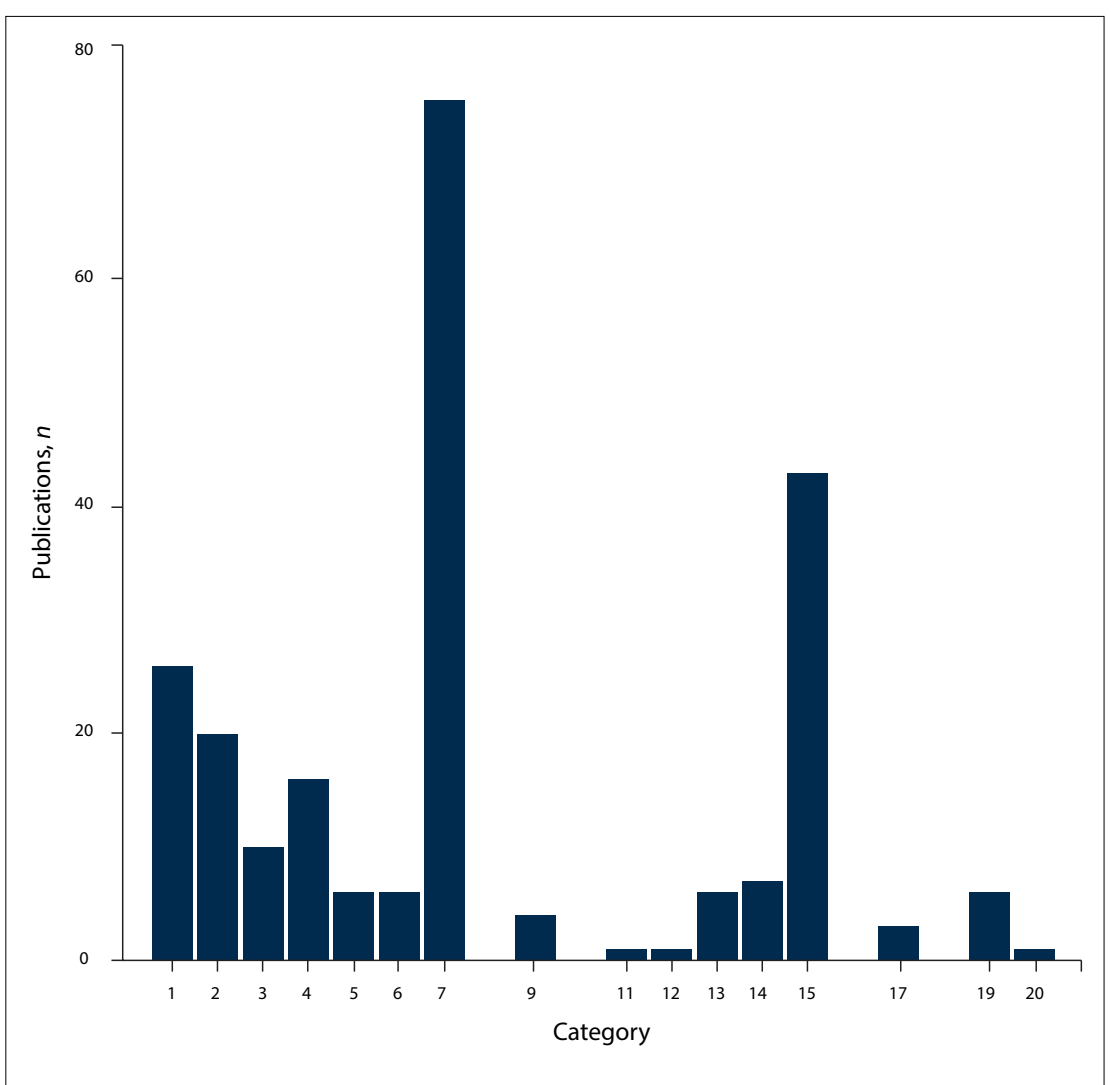

Fig. 4. Number of total publications per category from 1998 to 2015. There were no articles in categories $8,10,16$ and 18 .

was statistically significant $\left(r^{2}=0.8319\right.$; $p<0.001)$ between time and number of publications. A similar result was found when linear regression was run to access the relationship between time and impact factors; although $r^{2}$ was lower (0.5284), $p$ was still $<0.001$, showing a statistically significant association (Table 4).

\section{Discussion}

This bibliometric exercise aimed to identify published research articles on SA-related environmental health issues and to identify research gaps and opportunities for future research. We set out to determine which environmental health themes are most often published, in which institutions the work is being carried out and by whom, and the suite of journals in which environmental health science related to SA is being published. Our goal was to identify the research gaps in the light of the current environmental health challenges facing SA and to highlight opportunities for future research, especially through the use of existing and big data that we hope will help environmental health surveillance and disease tracking. However, as we progressed through the interpretation of the study findings, it became clear that a number of important, non-research-related issues that pertained to aligning accessibility of science to the profession of the science were as important.

From the retrieved studies in our dataset, the annual number of environmental health/SA-related articles has increased over the past 18 years. Several factors may have contributed to this increasing trend. For example, availability of research funding to support environmental health projects may have increased, and there may have been more postgraduate students at local universities completing projects and publishing their findings. Interestingly, despite the pressing concern of climate change effects on human health, and the key role of environmental health in this research domain, only two studies were retrieved that considered long-term climatic impacts on environmental health. The absolute number of articles retrieved and that met our inclusion criteria seemed low $(n=230)$ for an 18-year period. We compared our findings with a similar 10 -year European bibliometric study ${ }^{[1]}$ in which 6329 articles were included and found that their total represented articles published by 29 countries, so when this figure is averaged by number of countries, on average each country produced 218 articles over 10 years, which is comparable to our findings (despite the European study using a set of MeSH terms including 'environmental health', 'environmental exposure', 'environmental illness' or 'environmental epidemiology'). 
Table 4. The relationship between time (1998 - 2015) and the number and impact factor of retrieved articles over that period and included in this assessment

\begin{tabular}{lll}
\hline & \multicolumn{2}{c}{ Time $($ 1998 - 2015) } \\
\cline { 2 - 3 } & $p$-value & F-statistic \\
\hline Number of publications & $<0.001$ & 79.19 \\
Impact factor & $<0.001$ & 17.92
\end{tabular}

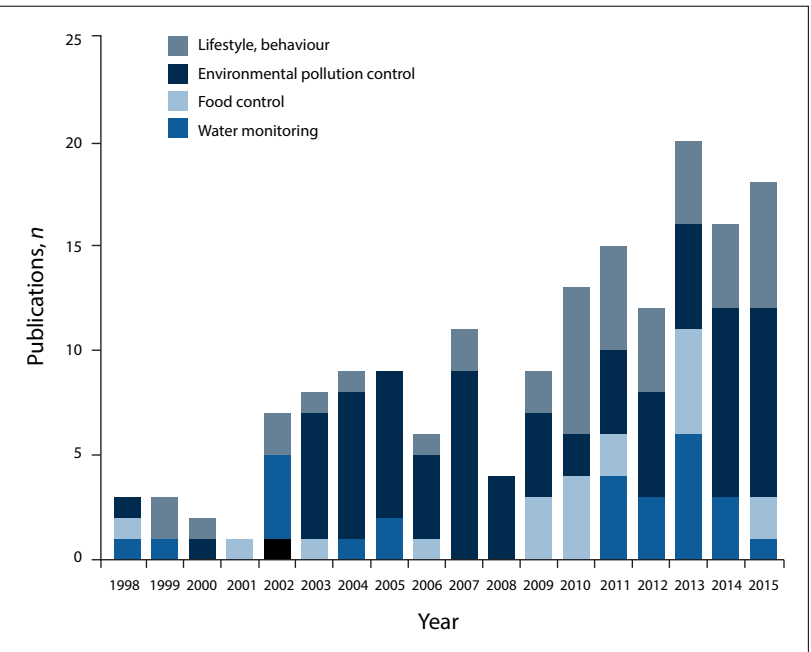

Fig. 5. Number of retrieved articles for the top three most frequently occurring environmental health categories by year from 1998 to 2015.

In our study, we used the MeSH exact thesaurus term match of 'environmental health'. There are nine phrase matches, and the MeSH tree for environmental health includes three terms, namely 'health physics', 'sanitation engineering' and 'sanitation'. Furthermore, the $\mathrm{MeSH}$ terms for 'environment and public health' closely follow the subtopics of environmental health, such as food inspection and environmental pollution, compared with those for environmental health. This poses a dilemma for researchers and others searching for the latest published environmental health topics, since the net of words one needs to apply in the search is large and complex. In bibliometric study of public health research in Africa, $<5 \%$ of authors added the phrase 'public health' to the author keywords list, even though the subject or subcategory subject fell into public health. ${ }^{[3]}$ Frequently authors referred to a specific disease in the keywords.

More than two-thirds of the retrieved articles were led by an author affiliated to an SA institution, with the University of Cape Town the most prolific. Similarly, the University of Cape Town was also the most prolific institution in Africa in terms of collaborating on article publication with other African countries between 2007 and 2011. ${ }^{[11]}$ The majority of retrieved articles were published in international journals with an impact factor of $<4$ (and $\sim 45 \%$ had impact factors of $<2$ ). While the impact factor is only one publication metric expressing the impact of research (other metrics exist, but in the present SA academic climate the impact factor holds as much weight as Department of Higher Education accreditation with regard to subsidy for article publication), these low figures do pose the question whether SA environmental health science is visible and accessible nationally and internationally. If this is not currently the case, researchers should consider ways in which to make it so, to ensure that local research can also have an influence in other low- and middleincome countries where environmental health issues are paramount.

Categorisation of the retrieved articles into environmental health subcategories research revealed that one-third of articles were related to environmental pollution and its control. Environmental pollution, i.e. water, air and soil pollution, is a challenging environmental health problem, particularly in countries with high levels of inequality and poverty such as SA. Relatively small numbers of articles were retrieved in the other subcategories, but this does not necessarily mean that they are under-researched. They may be, but it is more likely that they are indexed using different keywords, such as meat science for 'food control', and therefore do not appear in a search for environmental health. The example for occupational health was that one study with environmental and occupational health focus was included in our dataset. Occupational health is not a true subcategory of environmental health; it is its own field. In several studies where occupational health issues are concerned with environmental parameters, such as air pollution in an open-cast mine, environmental health concerns exist, but they fall under the jurisdiction of the mine safety, environment and health officer, and not the environmental health practitioner (EHP), who is tasked with community environmental health services. Nevertheless, the research may be relevant to the EHP and it would therefore be helpful if such articles were accessible when searching for pollution control as a subcategory of environmental health. Noise pollution, although a part of environmental health, did not appear in our dataset of retrieved studies, probably owing to lack of the words 'environmental health'. Such studies do exist for SA, such as a study that considered the environmental footprint of aircraft noise exposure at Cape Town International Airport. ${ }^{[12]}$ Of all the environmental health subcategories, it seems that 'disposal of the dead' is possibly the least researched topic.

\section{Study limitations}

Our searches were made in three indices, which may not include several local SA journals that also publish articles on environmental health and its subcategories for SA sites. These articles would not have been included here.

An important limitation is that the use of the keyword 'environmental health' is likely not to include all articles related to environmental health. For example, if studies used 'prevention', 'intervention' or a specific disease name such as schistosomiasis, without mentioning 'environmental health' anywhere in the title, abstract or author keywords, the article would not have been retrieved. Studies on malaria control or noise pollution, which are highly relevant to environmental health, are unlikely to be indexed as such. Either all environmental health-related articles should be indexed with 'environmental health', or when someone searches for environmental health topics, the search should be targeted to a subcategory topic of environmental health without that term. If this bibliometric review for SA were to be repeated, it is recommended that all environmental health MeSH terms should be explored.

A local limitation may also relate to a change in government terminology from 'municipal health services' to 'environmental health services' in the 2000s. This could have affected the search return for articles published in the 1990s, when 'municipal health services' may have been used. Future research may also consider using the Social Science Citation Index, since environmental health perceptions and psychologies may be described in studies published by the social sciences in addition to the natural and health sciences.

\section{Conclusions}

Environmental health research in SA and beyond spans a range of complex subjects and fields. With the emphasis on multiand interdisciplinary research to solve multifaceted problems, it is paramount that the research be retrievable and visible. This 
bibliometric review highlights the importance of standardised keywords across the environmental health research sector. The steady growth in research output, particularly in the past 3 years, is promising. The most frequently published field from our findings was environmental pollution control, which remains high on the SA policy agenda. As evident by first author publishers, the interest of the USA and UK in SA environmental health issues should be encouraged further through research collaboration. However, this study also highlights environmental health research collaborations that need to be nurtured.

Acknowledgements. We thank Nokulunga Cele and Patricia Albers for their assistance with data collection and preparation.

Author contributions. CYW conceptualised the study; FD performed the data collection and analysis; CYW, ZK and TK and RAS assisted with data analysis and presentation; CYW wrote the manuscript; and all co-authors contributed to its finalisation.

Funding. CYW and RAS receive funding from the South African Medical Research Council and the National Research Foundation.

Conflicts of interest. None.

1. World Health Organization. Deaths attributable to unhealthy environments. 2016. http://www.who. int/mediacentre/news/releases/2016/deaths-attributable-to-unhealthy-environments/en/ (accessed 17 February 2017).

2. Norman R, Bradshaw D, Lewin S, Cairncross SE, Nannan, N, Ffos T. Estimating the burden of diseases attributable to four selected environmental risk factors in South Africa. Rev Environ Health diseases attributable

3. Chuang K-Y, Chuang Y-C, Ho M, Ho Y-S. Bibliometric analysis of public health research in Africa: The overall trend and regional comparisons. S Afr J Sci 2011;107(5/6):1-6. https://doi.org/10.4102/ sajs.v107i5/6.309

Pouris AEM, Pouris A. An assessment of South Africass research journals: Eigenfactors and structure of editorial boards. S Afr J Sci 2015;111(3/4):1-8. https://doi.org/10.17159/sajs.2015/20130358

5. Li, T, Ho, Y-S, Li C-Y. Bibliometric analysis on global Parkinson's disease research trends. Neurosci Lett 2008;441(3):248-252. https://doi.org/10.1016/j.neulet.2008.06.044

6. World Health Organization. Public health, environmental and social determinants of health. 2017. http://www.who.int/phe/en/ (accessed 17 February 2017).

7. Cochrane Library. Environmental health definition. http://onlinelibrary.wiley.com/cochranelibrary/ search/mesh?searchRow.search Options. conceptId=D004782\&searchRow.searchCriteria. meshTerm=Environmental\%20Health\&meshConcept=Update\&searchRow.ordinal=0\&hiddenFields. strategySortBy=last-modified-date;desc\&hiddenFields.showStrategies=false (accessed 17 February strateg.
2017).

8. Carpenter CR, Cone DC, Sarli CC. Using publication metrics to highlight academic productivity and research impact. Acad Emerg Med 2014;21(10):1160-1172. https://doi.org/10.1111/acem.12482

9. Pouris A, Ho Y-S. Research emphasis and collaboration in Africa. Scientometrics 2014;98(3):21692184. https://doi.org/10.1007/s11192-013-1156-8

10. South Africa. Health Professions Act No. 56 of 1974. Regulations defining the scope of the profession of environmental health: amendment, 26 June 2009 (published under Government Notice R698).

11. Tarkowski SM. Environmental health research in Europe - bibliometric analysis. Eur J Public Health 2007;19(Suppl 1):14-18. https://doi.org/10.1093/eurpub/ckm065

12. Van der Merwe JH, von Holdt DS. Environmental footprint of aircraft noise exposure at Cape Town International Airport. S Afr Geogr J 2006;88(2):177-193. https://doi.org/10.1080/03736245.2006.9713860

Accepted 25 April 2017.

\section{Appendix 1. Articles included in this review}

Abalu G, Hassan R. Agricultural productivity and natural resource use in southern Africa. Food Policy 1998;23(6):477-490. https://doi.org/10.1016/s0306-9192(98)00056-6

Abbott J. The use of GIS in informal settlement upgrading: Its role and impact on the community and on cal government. Habitat Int 2003;27(4):575-593. https://doi.org/10.1016/s0197-3975(03)00006-7

Agenbag MH, Lues L, Lues JF. Compliance of local government towards controlling the informal milk-producing sector in South Africa. Int J Environ Health Res 2009;19(5):379-388. https://doi. $\mathrm{rg} / 10.1080 / 09603120902842713$

Albers P, Voyi K, Wright CY, Mathee A. Household fuel use and child respiratory ill health in two South African towns, Mpumalanga. S Afr Med J 2015;205(7):573-577. https://doi.org/10.7196/SAMJnew.7934

Allison MC. Balancing responsibility for sanitation. Soc Sci Med 2002;55(9):1539-1551. https://doi. org/10.1016/s0277-9536(01)00286-6

Ammar MG. Evaluation of the Green Egyptian Pyramid. Alexandria Eng J 2012;51(4):293-304. https:// doi.org/10.1016/j.aej.2012.09.002

Andersson E, Westberg H, Bryngelsson IL, Magnuson A, Persson B. Cancer incidence among Swedish pulp and paper mill workers: A cohort study of sulphate and sulphite mills. Int Arch Occup Environ Health pulp and paper mill workers: A cohort study of sulphate and sulphing
2013;86(5):529-540. https://doi.org/10.1007/s00420-012-0785-1

Andrade-Rivas F, Rother HA. Chemical exposure reduction: Factors impacting on South African herbicide Andrade-Rivas F Rother HA. Chemical exposure reduction: Factors impacting on South African herbicide
sprayers' personal protective equipment compliance and high risk work practices. Environ Res 2015;142:34-45. sprayers' personal protective equipment comp
https://doi.org/10.1016/j.envres.2015.05.028n

Andriessen R, Snetselaar J, Suer RA, et al. Electrostatic coating enhances bioavailability of insecticides and
A s $/ /$ doi.org/10.1016/j.envres.2015.05.028n breaks pyrethroid resistance in mosquitoes. Proc Nat Acad Sci U S A 2015;112(39):12081-12086. https://doi. org/10.1073/pnas.1510801112
Aneck-Hahn NH, Schulenburg GW, Bornman MS, Farias P, de Jager C. Impaired semen quality associated with environmental DDT exposure in young men living in a malaria area in the Limpopo Province, South Africa. J Androl 2007;28(3):423-434. https://doi.org/10.2164/jandrol.106.001701

Arjoon A, Olaniran AO, Pillay B. Enhanced 1,2-dichloroethane degradation in heavy metal coArjoon A, Olaniran AO, Pillay B. Enhanced 1,2-dichloroethane degradation in heavy metal co-
contaminated wastewater undergoing biostimulation and bioaugmentation. Chemosphere 2013;93(9):18261834. https://doi.org/10.1016/j.chemosphere.2013.06.034

Azimoh CL, Klintenberg P, Wallin F, Karlsson B. Illuminated but not electrified: An assessment of the impact of Solar Home System on rural households in South Africa. Appl Energy 2015;155:354-364. https:// doi.org/10.1016/j.apenergy.2015.05.120

Baatjies R, Lopata AL, Sander I, et al. Determinants of asthma phenotypes in supermarket bakery workers. Eur Respir J 2009;34(4):825-833. https://doi.org/10.1183/09031936.00164408

Baatjies R, Meijster T, Heederik D, Sander I, Jeebhay MF. Effectiveness of interventions to reduce flour dust exposures in supermarket bakeries in South Africa. Occup Environ Med 2014;71(12):811-818. https:/ doi.org/10.1136/oemed-2013-101971

Bachmann MO, Makan B. Salary inequality and primary care integration in South Africa. Soc Sci Med 1997;45(5):723-729. https://doi.org/10.1016/s0277-9536(96)00406-6

Barkemeyer R, Comyns B, Figge F, Napolitano G. CEO statements in sustainability reports: Substantive information or background noise? Account Forum 2014;38(4):241-257. https://doi.org/10.1016/j. accfor.2014.07.002

Barnes B, Mathee A, Moiloa K. Assessing child time - activity patterns in relation to indoor cooking fires in developing countries: A methodological comparison. Int J Hyg Environ Health 2005;208(3):219-225. https:// doi.org/10.1016/ji.ijheh.2005.01.022

Barnes BR. The politics of behavioural change for environmental health promotion in developing Barnes BR. The politics of behavioural change for environmental health promotion
countries. J Health Psychol 2007;12(3):531-538. https://doi.org/10.1177/1359105307076239

Barten F Santana VS, Rongo L, Varillas W, Pakasi TA. Contextualising workers' health and safety in urban settings: The need for a global perspective and an integrated approach. Habitat Int 2008;32(2):223-236. https:// doi.org/10.1016/i.habitatint.2007.08.017

Batterman S, Chernyak S, Gouden Y, Hayes J, Robins T, Chetty S. PCBs in air, soil and milk in industrialized and urban areas of KwaZulu-Natal, South Africa. Environ Pollut 2009;157(2):654-663. https:/ doi.org/10.1016/j.envpol.2008.08.015

Batterman S, Su FC, Jia C, Naidoo RN, Robins T, Naik I. Manganese and lead in children's blood and airborne particulate matter in Durban, South Africa. Sci Total Environ 2011;409(6):1058-1068. https://doi org/10.1016/j.scitotenv.2010.12.017

Batterman SA, Chernyak SM, Gounden Y, Matooane M, Naidoo RN. Organochlorine pesticides in ambient air in Durban, South Africa. Sci Total Environ 2008;397(1-3):119-130. https://doi.org/10.1016/j. scitotenv.2008.02.033

Bekker IL, Hoffman LC, Jooste P. Knowledge of stakeholders in the game meat industry and its effect on compliance with food safety standards. Int J Environ Health Res 2011;21(5):341-363. https://doi.org/10.1080 /09603123.2011.552715

Bell ML, O'Neill MS, Cifuentes LA, et al. Challenges and recommendations for the study of socioeconomic factors and air pollution health effects. Environ Sci Policy 2005;8(5):525-533. https://doi.org/10.1016/j. envsci.2005.06.003

Bischel HN, Özel Duygan BD, Strande L, McArdell CS, Udert KM, Kohn T. Pathogens and pharmaceuticals in source-separated urine in eThekwini, South Africa. Water Res 2015;85:57-65. https://doi.org/10.1016/j. in source-separated

Bond P. Basic infrastructure for socio-economic development, environmental protection and geographical desegregation: South Africa's unmet challenge. Geoforum 1999;30(1):43-59. https://doi.org/10.1016/s0016185(98)00031-

Bornman M, Schlemmer L, van der Walt T, van Dyk C, Bouwman H. Implications for health education and intervention strategies arising from children's caregivers concerns following successful malaria control. Trans R Soc Trop Med Hyg 2012;106(7):408-414. https://doi.org/10.1016/j.trstmh.2012.04.007 Bornman R, de Jager C, Worku Z, Farias P, Reif S. DDT and urogenital malformations in newborn boys in a malarial area. BJU Int 2010;106(3):405-411. https://doi.org/10.1111/j.1464-410x.2009.09003.x

Bourne LT, Harmse B, Temple N. Water: A neglected nutrient in the young child? A South African perspective. Matern Child Nutr 2007;3(4):303-311. https://doi.org/10.1111/j.1740-8709.2007.00114.x

Cameron J, Jagals P, Hunter PR, Pedley S, Pond K. Economic assessments of small-scale drinking-water interventions in pursuit of MDG target 7C. Sci Total Environ 2011;410-411:8-15. https://doi.org/10.1016/j. scitotenv.2011.09.054

Chanda RR, Fincham RJ, Venter P. A review of the South African food control system: Challenges of fragmentation. Food Control 2010;21(6):816-824. https://doi.org/10.1016/j.foodcont.2009.12.004

Channa K, Odland JØ, Kootbodien T, et al. Differences in prenatal exposure to mercury in South African communities residing along the Indian Ocean. Sci Total Environ 2013;463-464:11-19. https://doi. org/10.1016/.j.scitotenv.2013.05.055

Chelule PK, Mbongwa HP, Carries S, Gqaleni N. Lactic acid fermentation improves the quality of mahewu, a traditional South African maize-based porridge. Food Chem 2010;122(3):656-661. https://doi org/10.1016/j.foodchem.2010.03.026

Clark CS, Rampal KG, Thuppil V, et al. Lead levels in new enamel household paints from Asia, Africa and South America. Environ Res 2009;109(7):930-936. https://doi.org/10.1016/j.envres.2009.07.002

Collins JF, Salmon AG, Brown JP, Marty MA, Alexeeff GV. Development of a chronic inhalation reference level for respirable crystalline silica. Regul Toxicol Pharmacol 2005;43(3):292-300. https://doi.org/10.1016/j. yrtph.2005.08.003

Couth R, Trois C. Carbon emissions reduction strategies in Africa from improved waste management: A review. Waste Manag 2010;30(11):2336-2346. https://doi.org/10.1016/..wasman.2010.04.013

Cranston I, Potgieter N, Mathebula S, Ensink JHJ. Transmission of Enterobius vermicularis eggs through hands of school children in rural South Africa. Acta Trop 2015;150:94-96. https://doi.org/10.1016/j. actatropica.2015.07.001

Credé S, Sinanovic E, Adnams C, London L. The utilization of health care services by children with foetal alcohol syndrome in the Western Cape, South Africa. Drug Alcohol Depend 2011;115(3):175-182. https://doi org/10.1016/j.drugalcdep.2010.10.019

Criswell SR, Nelson G, Gonzalez-Cuyar LF, et al. Ex vivo magnetic resonance imaging in South African Criswell SR, Nelson G, Gonzalez-Cuyar LF, et al. Ex vivo magnetic resonance imaging in South Africa
manganese mine workers. Neurotoxicology 2015;49(July):8-14. https://doi.org/10.1016/.neuro.2015.04.002 Dabrowski JM, Shadung JM, Wepener V. Prioritizing agricultural pesticides used in South Africa based on their environmental mobility and potential human health effects. Environ Int 2014;62:31-40. https://doi org/10.1016/j.envint.2013.10.00

Dalal S, Holmes MD, Laurence C, et al. Feasibility of a large cohort study in sub-Saharan Africa assessed hrough a four-country study. Global Health Action 2015;8(1):27422. https://doi.org/10.3402/gha.v8.27422 Dalvie MA, Africa A, London L. Change in the quantity and acute toxicity of pesticides sold in South African crop sectors, 1994 - 1999. Environ Int 2009;35(4):683-687. https://doi.org/10.1016/j.envint.2008.12.004 Dalvie MA, Africa A, Naidoo S. Relationship between firewood usage and urinary $\mathrm{Cr}, \mathrm{Cu}$ and $\mathrm{As}$ in informal areas of Cape Town. S Afr Med J 2014;104(1):61. https://doi.org/10.7196/samj.6451

Dalvie MA, Africa A, Solomons A, London L, Brouwer D, Kromhout H. Pesticide exposure and bloo endosulfan levels after first season spray amongst farm workers in the Western Cape, South Africa. J Environ Sci Health B 2009;44(3):271-277. https://doi.org/10.1080/03601230902728351

Dalvie MA, Ehrlich R. Community mercury levels in the vicinity of peri-urban waste disposal sites an fossil fuel burning operations. Environ Int 2006;32(4):493-499. https://doi.org/10.1016/j.envint.2005.11.003 Dalvie MA, London L. The impact of aerial application of organophosphates on the cholinesterase levels of rural residents in the Vaalharts district, Northern Cape Province, South Africa. Environ Res 2006;102(3):326332. https://doi.org/10.1016/j.envres.2006.01.008 
Dalvie MA, London L. Risk assessment of pesticide residues in South African raw wheat. Crop Prot 2009;28(10):864-869. https://doi.org/10.1016/..cropro.2009.07.008

Dalvie MA, Myers JE. The relationship between reproductive outcome measures in DDT exposed malaria vector control workers: A cross-sectional study. J Occup Med Toxicol 2006;1:21. http://dx.doi. org/10.1186/1745-6673-1-21

Dalvie MA, Myers JE, Lou Thompson M, et al. The hormonal effects of long-term DDT exposure among malaria vector-control workers in Limpopo Province, South Africa. Environ Res 2004;96(1):9-19. https://doi org/10.1016/j.envres.2003.09.003

Dalvie MA, Myers JE, Thompson ML, et al. The long-term effects of DDT exposure on semen, fertility, and sexual function of malaria vector-control workers in Limpopo Province, South Africa. Environ Res 2004;96(1):1-8. https://doi.org/10.1016/j.envres.2003.09.002

Dalvie MA, Myers JE, Thompson ML, Robins TG, Omar S, Riebow J. Exploration of different methods for measuring DDT exposure among malaria vector-control workers in Limpopo Province, South Africa. Environ Res 2004;96(1):20-27. https://doi.org/10.1016/i.envres.2003.09.004

Dalvie MA, Naik I, Channa K, London L. Urinary dialkyl phosphate levels before and after first season chlorpyrifos spraying amongst farm workers in the Western Cape, South Africa. J Environ Sci Health 2011;46(2):163-172. https:///oi.org/10.1080/03601234.2011.535384

Dalvie MA, Rother H-A, London L. Chemical hazard communication comprehensibility in South Africa: Safety implications for the adoption of the globally harmonised system of classification and labelling of chemicals. Safety Sci 2014;61:51-58. https://doi.org/10.1016/j.ssci.2013.07.013

Dalvie MA, Sinanovic E, London L, Cairncross E, Solomon A, Adam H. Cost analysis of ELISA, solidphase extraction, and solid-phase microextraction for the monitoring of pesticides in water. Environ Res 2005;98(1):143-150. https://doi.org/10.1016/j.envres.2004.09.002

Dalvie MA, Sosan MB, Africa A, Cairncross E, London L. Environmental monitoring of pesticide residues from farms at a neighbouring primary and pre-school in the Western Cape in South Africa. Sci Total Environ 2014;466-467:1078-1084 https://doi.org/10.1016/j.scitotenv.2013.07.099

Darkey D, Visagie J. The more things change the more they remain the same: A study on the quality of life in an informal township in Tshwane. Habitat Int 2013;39:302-309. https://doi.org/10.1016/j. habitatint.2012.10.016

Davies TC. Geochemical variables as plausible aetiological cofactors in the incidence of some common environmental diseases in Africa.J Afr Earth Sci 2013;79:24-49. https://doi.org/10.1016/j.jafrearsci2012.11.002 Davies TC Mundalamo HR. Envionmental health impacts of dispersed mineralistion in South Africa. I Afr Earth Sci 2010;58(4):652-666. https://doi.org/10.1016/j.jafrearsci.2010.08.009

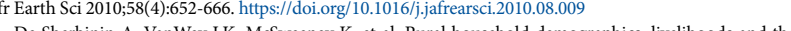
De Sherbinin A, VanWey LK, McSweeney K, et al. Rural household demographics, livelihoods and
nvironment. Glob Environ Change 2008:18(1):38-53. https://doi.org/10.1016/j.gloenvcha.2007.05.005

Dickens CWS, Graham PM. Biomonitoring for effective management of wastewater discharges and the health of the river environment. Aquat Ecosyst Health Manag 1998;1(2):199-217. https://doi org/10.1080/14634989808656914

Djawe K, Daly KR, Levin L, Zar HJ, Walzer PD. Humoral immune responses to Pneumocystis jiroveci antigens in HIV-infected and uninfected young children with pneumocystis pneumonia. PLoS One 2013;8(12):e82783. https://doi.org/10.1371/journal.pone.0082783

Ehrlich R. A century of miners' compensation in South Africa. Am J Ind Med 2012;55(6):560-569. https:// doi.org/10.1002/ajim.22030

Ehrlich RI, Adams S, Baatijes R, Jeebhay MF. Chronic airflow obstruction and respiratory symptoms following tuberculosis: A review of South African studies. Int J Tuberc Lung Dis 2011;15(7):886-891. https:// doi.org/10.5588/ijtld.10.0526

English RG, Perry M, Lee MM, Hoffman E, Delport S, Dalvie MA. Farm residence and reproductive health among boys in rural South Africa. Environ Int 2012;47:73-79. https://doi.org/10.1016/..envint.2012.06.006 Erasmus LJ, Potgieter MJ, Semenya SS, Lennox SJ. Phytomedicine versus gonorrhoea: The Bapedi experience. Afr J Trad Complement Altern Med 2012;9(4):591-598. https://doi.org/10.4314/aitcam.v9i4.17

Eskenazi B, Quirós-Alcalá L, Lipsitt JM, et al. mSpray: A mobile phone technology to improve malaria control efforts and monitor human exposure to malaria control pesticides in Limpopo, South Africa. Environ Int 2014;68:219-226. https://doi.org/10.1016/..envint.2014.03.003

Ezeah C, Fazakerley JA, Roberts CL. Emerging trends in informal sector recycling in developing and transition countries. Waste Manage 2013;33(11):2509-2519. https://doi.org/10.1016/j.wasman.2013.06.020

Fearon E, Wiggins RD, Pettifor AE, Hargreaves JR. Is the sexual behaviour of young people in sub-Sahara

Africa influenced by their peers? A systematic review. Soc Sci Med 2015;146:62-74. https://doi.org/10.1016/j.

socscimed.2015.09.039

Few R, Gouveia N, Mathee A, et al. Informal sub-division of residential and commercial buildings in São Paulo and Johannesburg: Living conditions and policy implications. Habitat Int 2004;28(3):427-442. https:// doi.org/10.1016/s0197-3975(03)00042-0

Fuertes E, Butland BK, Ross Anderson H, Carlsten C, Strachan DP, Brauer M. Childhood intermittent and persistent rhinitis prevalence and climate and vegetation: A global ecologic analysis. Ann Allergy Asthma and persistent rhinitis prevalence and climate and vegetation: A global ecologic
Immunol 2014;113(4):386-392.e9. https://doi.org/10.1016/.anai.2014.06.021

Garland R, Matoaane M, Engelbrecht E, et al. Regional projections of extreme apparent temperature days in Africa and the related potential risk to human health. Int J Environ Res Public Health 2015;12(10):1257712604. https://doi.org/10.3390/ijerph121012577

Gaspar FW, Chevrier J, Bornman R, et al. Undisturbed dust as a metric of long-term indoor insecticide exposure: Residential DDT contamination from indoor residual spraying and its association with serum levels in the VHEMBE cohort. Environ Int 2015;85:163-167. https://doi.org/10.1016/j.envint.2015.09.014

Gemmell ME, Schmidt S. Microbiological assessment of river water used for the irrigation of fresh produce in a sub-urban community in Sobantu, South Africa. Food Res Int 2012;47(2):300-305. https://doi org/10.1016/j.foodres.2011.07.016

Goble BJ, Lewis M, Hill TR, Phillips MR. Coastal management in South Africa: Historical perspectives and setting the stage of a new era. Ocean Coast Manag 2014;91:32-40. https://doi.org/10.1016/j. ocecoaman.2014.01.013

Godfrey-Faussett P, Sonnenberg P, Shearer SC, et al. Tuberculosis control and molecular epidemiology in a South African goll

6736(00)02730-6

Goebel A, Dodson B, Hill T. Urban advantage or urban penalty? A case study of female-headed household in a South African city Health Place 2010:16(3):573-580. https//doi org /10.1016/jhealthplace 2010.01.002 Gonzalez-Cuyar LF, Nelson G, Criswell SR, et al. Quantitative neuropathology associated with chronic manganese exposure in South African mine workers. Neurotoxicology 2014;45(Dec):260-266. https://doi org/10.1016/j.neuro.2013.12.008

Govender N, Lalloo UG, Naidoo RN. Occupational exposures and chronic obstructive pulmonary disease: A hospital based case-control study. Thorax 2011;66(7):597-601. https://doi.org/10.1136/thx.2010.149468 Gwenzi W, Mupatsi NM. Evaluation of heavy metal leaching from coal ash-versus conventional concr monoliths and debris. Waste Manage 2016;49:114-123. https://doi.org/10.1016/j.wasman.2015.12.029 Gyalpo T, Fritsche L, Bouwman H, Bornman R, Scheringer M, Hungerbühler K. Estimation of huma body concentrations of DDT from indoor residual spraying for malaria control. Environ Pollut 2012;169:235241. https://doi.org/10.1016/j.envpol.2012.04.032

Guy CY, Diab RD. A health risk assessment of ultraviolet radiation in Durban. S Afr Geogr J 2002;84(2):208-213. https://doi.org/10.1080/03736245.2002.9713772

Harmse JL, Engelbrecht JC. Air sampling of nickel in a refinery. Int J Environ Health Res 2007;17(4):319325. https://doi.org/10.1080/09603120701372698

Harmse JL, Engelbrecht JC, Bekker JL. The impact of physical and ergonomic hazards on poultry abattoi Harmse JL, Engelbrecht JC, Bekker JL. The impact of physical and ergonomic hazards on poultry abattoir
processing workers: A review. Int J Environ Res Public Health 2016;13(2):197. https://doi.org/10.3390/ ijerph13020197
Hess CA, Smith MJ, Trueman C, Schutkowski H. Longitudinal and contemporaneous manganese xposure in apartheid-era South Africa: Implications for the past and future. Int J Paleopathol 2015;8:1-9. https://doi.org/10.1016/j.jpp.2014.09.005

Hoque ME, Ghuman S, Coopoosmay R, van Hal G. Cervical cancer screening among university students in South Africa: A theory based study. PLoS One 2014;9(11):el11557. https://doi.org/10.1371/journal.pone.0111557 Jafta N, Batterman SA, Gqaleni N, Naidoo RN, Robins TG. Characterization of allergens and airborne fungi in low and middle-income homes of primary school children in Durban, South Africa. Am J Ind Med 2012;55(12):1110-1121. https://doi.org/10.1002/ajim.2208

Jafta N, Jeena PM, Barregard L, Naidoo RN. Childhood tuberculosis and exposure to indoor air pollution: A systematic review and meta-analysis. Int J Tuberc Lung Dis 2015;19(5):596-602. https://doi.org/10.5588/ ijtld.14.0686

Jassat W, Naicker N, Naidoo S, Mathee A. Rodent control in urban communities in Johannesburg, South Africa: From research to action. Int J Environ Health Res 2013;23(6):474-483. https://doi.org/10.1080/09603 123.2012.755156

Jeebhay MF, Baatjies R, Chang YS, et al. Risk factors for allergy due to the two-spotted spider mite (Tetranychus urticae) among table grape farm workers. Int Arch Allergy Immunol 2007;144(2):143-149. https://doi.org/10.1159/000103226

Jeebhay MF, Quirce S. Occupational asthma in the developing and industrialised world: A review. Int J Tuberc Lung Dis 2007;11(2):122-133.

Jeebhay MF, Robins TG, Miller ME, et al. Occupational allergy and asthma among salt water fish processing workers. Am J Ind Med 2008;51(12):899-910. https://doi.org/10.1002/ajim.20635

Jeebhay MF, Robins TG, Seixas N, et al. Environmental exposure characterization of fish processing workers. Ann Occup Hyg 2005;49(5):423-437. https://doi.org/10.1093/annhyg/meh113

John J, Wright CY, Oosthuizen MA, et al. Environmental health outcomes and exposure risks among at-risk communities living in the Upper Olifants River Catchment, South Africa. Int J Environ Health Res 2014;24(3):195-214. https://doi.org/10.1080/09603123.2013.80732

Katwan E, Adnams C, London L. Childhood behavioural and developmental disorders: Association with aternal alcohol consumption in Cape Town, South Africa. S Afr Med J 2011;101(10):724,726-727.

Kimemia D, Vermaak C, Pachauri S, Rhodes B. Burns, scalds and poisonings from household energy use in South Africa: Are the energy poor at greater risk? Energy Sustain Dev 2014;18:1-8. https://doi.org/10.1016/j. esd.2013.11.011

King CH, Dickman K, Tisch DJ. Reassessment of the cost of chronic helmintic infection: A meta-analysis of disability-related outcomes in endemic schistosomiasis. Lancet 2005;365(9470):1561-1569. https://doi. org/10.1016/s0140-6736(05)66457-4

Kolawole OD. Soils, science and the politics of knowledge: How African smallholder farmers are framed and situated in the global debates on integrated soil fertility management. Land Use Policy 2013;30(1):470-484. https://doi.org/10.1016/j.landusepol.2012.04.006

Kusangaya S, Warburton ML, Archer van Garderen E, Jewitt GPW. Impacts of climate change on water resources in southern Africa: A review. Phys Chem Earth 2014;67-69:47-54. https://doi.org/10.1016/j. pce.2013.09.014

Labonte R, Sanders D, Packer C, Schaay N. Is the Alma Ata vision of comprehensive primary health care viable? Findings from an international project. Global Health Act 2014;7:24997. https://doi.org/10.3402/gha. 7.24997

Lambrechts AA, Human IS, Doughari JH, Lues JFR. Microbiological contamination of the hands of food handlers as indicator of hand washing efficacy in some convenient food industries in South Africa. Pak J Med Sci 2014;30(4):755-758. https://doi.org/10.12669/pjms.304.4400

Lerer LB, Scudder T. Health impacts of large dams. Environ Impact Assess Rev 1999;19(2):113-123. https://doi.org/10.1016/s0195-9255(98)00041-9

Lobstein T, Jackson-Leach R, Moodie ML, et al. Child and adolescent obesity: Part of a bigger picture. Lobstein T, Jackson-Leach R, Moodie ML, et al. Child and adolescent obesity:
Lancet 2015;385(9986):2510-2520. https://doi.org/10.1016/s0140-6736(14)61746-3

London L. The 'dop' system, alcohol abuse and social control amongst farm workers in South Africa: A public health challenge. Soc Sci Med 1999;48(10):1407-1414. https://doi.org/10.1016/s0277-9536(98)00445-6 London L. Alcohol consumption amongst South African farm workers: A challenge for post-apartheid health sector transformation. Drug Alcohol Depend 2000;59(2):199-206. https://doi.org/10.1016/s03768716(99)00120-9

London L. Dual loyalties and the ethical and human rights obligations of occupational health professionals. Am J Ind Med 2005;47(4):322-332. https://doi.org/10.1002/ajim.20148

London L. Neurobehavioural methods, effects and prevention: Workers' human rights are why the field matters for developing countries. Neurotoxicology 2009;30(6):1135-1143. https://doi.org/10.1016/j. neuro.2009.01.007

London L, Beseler C, Bouchard MF, et al. Neurobehavioral and neurodevelopmental effects of pesticide exposures. Neurotoxicology 2012;33(4):887-896. https://doi.org/10.1016/..neuro.2012.01.004

London L, Bourne D, Sayed R, Eastman R. Guillain-Barre syndrome in a rural farming district in South Africa: A possible relationship to environmental organophosphate exposure. Arch Environ Health 2004;59(11):575-580. https://doi.org/10.1080/00039890409603436

London L, Coggon D, Moretto A, Westerholm P, Wilks MF, Colosio C. The ethics of human volunteer studies involving experimental exposure to pesticides: Unanswered dilemmas. Environ Health 2010;9:50, https://doi.org/10.1186/1476-069x-9-50

London L, Flisher AJ, Wesseling C, Mergler D, Kromhout H. Suicide and exposure to organophosphate insecticides: Cause or effect? Am J Ind Med 2005;47(4):308-321. https://doi.org/10.1002/ajim.20147

London L, Rother HA. People, pesticides, and the environment: Who bears the brunt of backward policy in

South Africa? New Solut 2000;10(4):339-350. https://doi.org/10.2190/hagw-qu9e-4h86-aw6w

Lubick N. Examining DDT’s urogenital effects. Environ Health Perspect 2010;118(1):A18. https://doi. rg/10.1289/ehp.118-a18

Lues JFR, Venter P, van der Westhuizen H. Enumeration of potential microbiological hazards in milk from a marginal urban settlement in central South Africa. Food Microbiol 2003;20(3):321-326. https://doi. org/10.1016/s0740-0020(02)00128-4

Lundin M, Morrison GM. A life cycle assessment based procedure for development of environmental sustainability indicators for urban water systems. Urban Water 2002;4(2):145-152. https://doi.org/10.1016/ s1462-0758(02)00015-8

Luyt CD, Tandlich R, Muller WJ, Wilhelmi BS. Microbial monitoring of surface water in South Africa: An overview. Int J Environ Res Public Health 2012;9(8):2669-2693. https://doi.org/10.3390/ijerph9082669 Majuru B, Jagals P, Hunter PR. Assessing rural small community water supply in Limpopo, South Africa: Water service benchmarks and reliability. Sci Total Environ 2012;435-436:479-486. https://doi.org/10.1016/j. citotenv.2012.07.024

Majuru B, Mokoena MM, Jagals P, Hunter PR. Health impact of small-community water supply reliability. Int J Hyg Environ Health 2011;214(2):162-166. https://doi.org/10.1016/.ijheh.2010.10.005

Mandelli S, Barbieri J, Mattarolo L, Colombo E. Sustainable energy in Africa: A comprehensive data and policies review. Renew Sustain Energy Rev 2014;37:656-686. https://doi.org/10.1016/j.rser.2014.05.069 Manrakhan A, Kotze C, Daneel JH, Stephen PR, Beck RR. Investigating a replacement for malathion in bait sprays for fruit fly control in South African citrus orchards. Crop Prot 2013;43 (Jan 2013):45-53. https:// doi.org/10.1016/j.cropro.2012.09.010

Mathee A. Environment and health in South Africa: Gains, losses, and opportunities. I Public Health Policy 2011;32(Suppl 1):S37-S43. https://doi.org/10.1057/jphp.2011.21

Mathee A. Towards the prevention of lead exposure in South Africa: Contemporary and emerging challenges. Neurotoxicology 2014;45 (Dec 2014):220-223. https://doi.org/10.1016/j.neuro.2014.07.007 Mathee A, Naicker N. The socioeconomic and environmental health situation of international migrants in
Johannesburg, South Africa. S Afr Med J 2016;106(1):70-75. https://doi.org/10.7196/SAMJ.2016.v106il.10215 
Matinga MN, Annegarn HJ, Clancy JS. Healthcare provider views on the health effects of biomass fuel collection and use in rural Eastern Cape, South Africa: An ethnographic study. Soc Sci Med 2013;97:192 200. https://doi.org/10.1016/.jsocscimed.2013.08.015

Mbiba B. Urban solid waste characteristics and household appetite for separation at source in Eastern and Southern Africa. Habitat Int 2014;43:152-162. https://doi.org/10.1016/j.habitatint.2014.02.001

Mee P, Collinson MA, Madhavan S, et al. Determinants of the risk of dying of HIV/AIDS in a rural South African community over the period of the decentralised roll-out of antiretroviral therapy: A longitudinal study. Global Health Act 2014;7:24826. https://doi.org/10.3402/gha.v7.24826

Mellor JE, Smith JA, Samie A, Dillingham RA. Coliform sources and mechanisms for regrowth in household drinking water in Limpopo, South Africa. J Environ Eng 2013;139(9):1152-1161. https://doi. org/10.1061/(asce)ee.1943-7870.0000722

Mendelsohn J, Dawson T. Climate and cholera in KwaZulu-Natal, South Africa: The role of environmental factors and implications for epidemic preparedness. Int J Hyg Environ Health 2008;211(12):156-162. https://doi.org/10.1016/j.ijheh.2006.12.002

Mfenyana K, Griffin M, Yogeswaran P, et al. Socio-economic inequalities as a predictor of health in South Africa - the Yenza cross-sectional study. S Afr Med J 2006;96(4):323-330.

Mhlongo SE, Amponsah-Dacosta F, Mphephu NF. Rehabilitation prioritization of abandoned mines and its application to Nyala magnesite mine. J Afr Earth Sci 2013;88:53-61. https://doi.org/10.1016/j. jafrearsci.2013.08.007

Moatamed F, Lockey JE, Parry WT. Fiber contamination of vermiculites: A potential occupational and environmental health hazard. Environ Res 1986;41(1):207-218. https://doi.org/10.1016/s0013and environmen

Molelekwa GF, Mukhola MS, van der Bruggen B, Luis P. Preliminary studies on membrane filtration for the production of potable water: A case of Tshaanda rural village in South Africa. PLoS One for the production of potable water: A case of Tshaanda ru
2014; 9 (8):e105057. https://doi.org/10.1371/journal.pone. 0105057

Momba MNB, Kaleni P. Regrowth and survival of indicator microorganisms on the surfaces of household containers used for the storage of drinking water in rural communities of South Africa. Water Res 2002;36(12):3023-3028. https://doi.org/10.1016/s0043-1354(02)00011-8

Musakwa W, Niekerk AV. Implications of land use change for the sustainability of urban areas: A case study of Stellenbosch, South Africa. Cities 2013;32:143-156. https://doi.org/10.1016/.j.ities.2013.01.004

Mwabi JK, Adeyemo FE, Mahlangu TO, et al. Household water treatment systems: A solution to the production of safe drinking water by the low-income communities of southern Africa. Phys Chem Earth 2011;36(14-15):1120-1128. https://doi.org/10.1016/j.pce.2011.07.078

Myers J, Young T, Galloway M, Manyike P, Tucker T,

Myers J, Young T, Galloway M, Manyike P. Tucker T. A public health approach to the impact of climate change on health in southern Africa - identifying priority modifiable risks. S Afr Med J 2011;101(11):817-820. Myers JE, Fine J, Ormond-Brown D, Fry J, Thomson A, Thompson ML. Estimating the prevalence of clinical manganism using a cascaded screening process in a South African manganese smelter. of clinical manganism using a cascaded screening process in a South Africn

Myers JE, Naude J, Fourie M, et al. nervous system effects of occupational manganese exposure on Myers JE, Naude J, Fourie M, et al. nervous system effects of occupational manganese exposure on
South African manganese mineworkers. Neurotoxicology 2003;24(4-5):649-656. https://doi.org/10.1016/ South African mangane
s0161-813x(03)00035-4

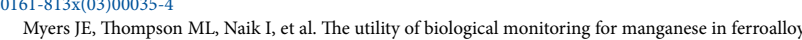

smelter workers in South Africa. Neurotoxicology 2003;24(6):875-883. https://doi.org/10.1016/s016

$813 \mathrm{x}(03) 00082-2$

Myers JE, Thompson ML, Ramushu S, et al. The nervous system effects of occupational exposure on workers in a South African manganese smelter. Neurotoxicology 2003;24(6):885-894. https://doi. org/10.1016/s0161-813x(03)00081-0

Nagiah S, Phulukdaree A, Naidoo D, et al. Oxidative stress and air pollution exposure during pregnancy: molecular assessment. Hum Exp Toxicol 2015;34(8):838-847. https://doi.org/10.1177/0960327114559992 Nahman A. Extended producer responsibility for packaging waste in South Africa: Current approaches and lessons learned. Resour Conserv Recy 2010;54(3):155-162. https://doi.org/10.1016/j. resconrec,2009.07.006

Naicker N, Norris SA, Mathee A, Becker P, Richter L. Lead exposure is associated with a delay in the nset of puberty in South African adolescent females: Findings from the Birth to Twenty cohort. Sci Total onset of puberty in South African adolescent females: Findings from the Birth to
Environ 2010;408(21):4949-4954. https://doi.org/10.1016/i.scitotenv.2010.07.037

Naicker N, Norris SA, Mathee A, von Schirnding YE, Richter L. Prenatal and adolescent blood lead evels in South Africa: Child, maternal and household risk factors in the Birth to Twenty cohort. Environ levels in South Africa: Child, maternal and household risk factors in the

Naidoo R, Seixas N, Robins T. Estimation of respirable dust exposure among coal miners in South frica. J Occup Environ Hyg 2006;3(6):293-300. https://doi.org/10.1080/15459620600668973

Naidoo RN. Mining: South Africa's legacy and burden in the context of occupational respiratory diseases. Global Health Act 2013;6:1-3. https://doi.org/10.3402/gha.v6i0.20512

Naidoo RN, Haq SA. Occupational use syndromes. Best Pract Res Clin Rheumatol 2008;22(4):677-691. https://doi.org/10.1016/j.berh.2008.04.001

Naidoo RN, Jeebhay MF, Robins TG, Myers JE, Nogueira C, Zeleznik WS. Addressing the challenges of underdevelopment in environmental and occupational health in southern Africa. Int J Occup Environ Health 2006;12(4):392-399. https://doi.org/10.1179/oeh.2006.12.4.392

Naidoo RN, Robins TG, Batterman S, Mentz G, Jack C. Ambient pollution and respiratory outcomes among schoolchildren in Durban, South Africa. S Afr J Child Health 2013;7(4):127-134. https://doi. org/10.7196/sajch.598

Naidoo RN, Robins TG, Becklake M, Seixas N, Thompson ML. Cross-shift peak expiratory flow changes are unassociated with respirable coal dust exposure among South African coal miners. Am J Ind Med 2007;50(12):992-998. https://doi.org/10.1002/ajim.20513

Naidoo RN, Robins TG, Murray J. Respiratory outcomes among South African coal miners at autopsy. Am J Ind Med 2005;48(3):217-224. https://doi.org/10.1002/ajim.20207

Naidoo RN, Robins TG, Murray J, Green FH, Vallyathan V. Validation of autopsy data for epidemiologic studies of coal miners. Am J Ind Med 2005;47(1):83-90. https://doi.org/10.1002/ajim.20112

Naidoo RN, Robins TG, Seixas N, Lalloo UG, Becklake M. Differential respirable dust related lung function effects between current and former South African coal miners. Int Arch Occup Environ Health 2005;78(4):293-302. https://doi.org/10.1007/s00420-005-0602-1

Naidoo RN, Robins TG, Seixas N, Lalloo UG, Becklake M. Respirable coal dust exposure and respiratory symptoms in South-African coal miners: A comparison of current and ex-miners. J Occup Environ Med 2006;48(6):581-590. https://doi.org/10.1097/01.jom.0000200875.99411.03

Naidoo S, Jinabhai CC. TB in health care workers in KwaZulu-Natal, South Africa. Int J Tuberc Lung Dis 2006;10(6):676-682

Naidoo S, Kromhout H, London L, Naidoo RN, Burdorf A. Musculoskeletal pain in women working in small-scale agriculture in South Africa. Am J Ind Med 2009;52(3):202-209. https://doi.org/10.1002/ ajim. 20662

Naidoo S, London L, Burdorf A, Naidoo R, Kromhout H. Spontaneous miscarriages and infant deaths among female farmers in rural South Africa. Scand J Work Environ Health 2011;37(3):227-236. https://doi. org $/ 10.5271 /$ sjweh. 3133

Naidoo S, London L, Burdorf A, Naidoo RN, Kromhout H. Agricultural activities, pesticide use and occupational hazards among women working in small scale farming in northern KwaZulu-Natal, South Africa. Int J Occup Environ Health 2008;14(3):218-224. https://doi.org/10.1179/oeh.2008.14.3.218

Naidoo S, London L, Burdorf A, Naidoo RN, Kromhout H. Occupational activities associated with a reported history of malaria among women working in small-scale agriculture in South Africa. Am J Trop Med Hyg 2011;85(5):805-810. https://doi.org/10.4269/ajtmh.2011.11-0092
Naidoo S, London L, Rother HA, Burdorf A, Naidoo RN, Kromhout H. Pesticide safety training and practices in women working in small-scale agriculture in South Africa. Occup Environ Med 2010;67(12):823828. https://doi.org/10.1136/oem.2010.055863

Naidoo S, Seevnarain K, Nordstrom DL. Tuberculosis infection control in primary health clinics in eThekwini, KwaZulu-Natal, South Africa. Int J Tuberc Lung Dis 2012;16(12):1600-1604. https://doi rg/10.5588/ijtld.12.0041

Naiker Y, Diab RD, Zunckel M, Hayes ET. Introduction of local air quality management in South Africa: Overview and challenges. Environ Sci Policy 2012;17:62-71. https://doi.org/10.1016/j.envsci.2011.11.009 Nare L, Odiyo JO, Francis J, Potgieter N. Framework for effective community participation in water quality management in Luvuvhu catchment of South Africa. Phys Chem Earth 2011;36(14-15):1063-1070. https://doi org/10.1016/j.pce.2011.08.006

Ndlovu V, Dalvie MA, Jeebhay MF. Asthma associated with pesticide exposure among women in rura Western Cape of South Africa. Am J Ind Med 2014;57(12):1331-1343. https://doi.org/10.1002/ajim.22384

Nemathaga F, Maringa S, Chimuka L. Hospital solid waste management practices in Limpopo Province, South Africa: A case study of two hospitals. Waste Manag 2008;28(7):1236-1245. https://doi.org/10.1016/j. wasman.2007.03.033

Ngcobo M, Nkala B, Moodley I, Gqaleni N. Recommendations for the development of regulatory guidelines for registration of traditional medicines in South Africa. Afr J Tradit Complement Altern Med 2012;9(1):59-66. https://doi.org/10.4314/aitcam.v9i1.9

Ngcobo S, Jewitt GPW, Stuart-Hill SI, Warburton ML. Impacts of global change on southern African water ources systems. Curr Opin Environ Sustain 2013;5(6):655-666. https://doi.org/10.1016/j.cosust.2013.10.002 Nieuwenhuizen N, Lopata AL, Jeebhay MF, Herbert DBR, Robins TG, Brombacher F. Exposure to
fish parasite Anisakis causes allergic airway hyperreactivity and dermatitis. J Allergy Clin Immunol the fish parasite Anisakis causes allergic airway hyperreactivity
2006;117(5):1098-1105. https://doi.org/10.1016/.j.jaci.2005.12.1357

Nissing C, von Blottnitz H. An economic model for energisation and its integration into the urban energy planning process. Energy Policy 2010;38(5):2370-2378. https://doi.org/10.1016/j.enpol.2009.12.025

Nolan RP, Langer AM, Ross M, Addison J, Gee JBL. Non-occupational exposure to commercial amphibole asbestos and asbestos-related disease: Is there a role for grunerite asbestos (amosite)? Proc Geol Assoc 2007;118(1):117-127. https://doi.org/10.1016/S0016-7878(07)80052-6

Norman R, Bradshaw D, Lewin S, Cairncross SE, Nannan, N, Ffos T. Estimating the burden of disease attributable to four selected environmental risk factors in South Africa. Rev Environ Health 2010;25(2):87-119. https://doi.org/10.1515/reveh.2010.25.2.87

Nriagu JO, Blankson ML, Ocran K. Childhood lead poisoning in Africa: A growing public health problem. Sci Total Environ 1996;181(2):93-100. https://doi.org/10.1016/0048-9697(95)04954-1

Nsibande SA, Dabrowski JM, van der Walt E, Venter A, Forbes PBC. Validation of the AGDISP model for predicting airborne atrazine spray drift: A South African ground application case study. Chemosphere 2015;138:454-461. https://doi.org/10.1016/j.chemosphere.2015.06.092

Ochieng AA, Dalvie MA, Little F, Kromhout H. Relationship between environmental exposure to pesticides and anthropometric outcomes of boys in the rural Western Cape, South Africa. S Afr Med 2013;103(12):942-947. https://doi.org/10.7196/SAMJ.6942

Olaniran AO, Balgobind A, Pillay B. Impacts of heavy metals on 1,2-dichloroethane biodegradation in cocontaminated soil. J Environ Sci 2009;21(5):661-666. https://doi.org/10.1016/s1001-0742(08)62322-0

Olthuis K, Benni J, Eichwede K, Zevenbergen C. Slum upgrading: Assessing the importance of location and a plea for a spatial approach. Habitat Int 2015;50:270-288. https://doi.org/10.1016/j habitatint.2015.08.033

Olufemi O. Health of the homeless street women in South Africa. Habitat Int 1999;23(4):481-493. https:/ doi.org/10.1016/s0197-3975(99)00022-3

Onda K, Crocker J, Kayser GL, Bartram J. Country clustering applied to the water and sanitation sector: A new tool with potential applications in research and policy. Int J Hygiene Environ Health 2014;217(2-3):379385. https://doi.org/10.1016/j.ijheh.2013.07.017

Parbhoo A, Louw QA, Grimmer-Somers K. Burn prevention programs for children in developin countries require urgent attention: A targeted literature review. Burns 2010;36(2):164-175. https://doi org/10.1016/j.burns.2009.06.215

Parnell S, Walawege R. Sub-Saharan African urbanisation and global environmental change. Glob Environ Change 2011;21(Suppl 1):S12-S20. https://doi.org/10.1016/j.gloenvcha.2011.09.014

Phaswana SM, Naidoo S. The prevalence of latex sensitisation and allergy and associated risk factor among healthcare workers using hypoallergenic latex gloves at King Edward VIII Hospital, KwaZuluNatal, South Africa: A cross-sectional study. BMJ Open 2013;3(12):e002900. https://doi.org/10.1136/ bmjopen-2013-002900

Phoku JZ, Barnard TG, Potgieter N, Dutton MF. Fungi in housefly (Musca domestica L.) as a disease risk indicator - a case study in South Africa. Acta Trop 2014;140:158-165. https://doi.org/10.1016/j. tatropica.2014.08.019

Phoku JZ, Barnard TG, Potgieter N, Dutton MF. Fungal dissemination by housefly (Musca domestica L.) and contamination of food commodities in rural areas of South Africa. Int J Food Microbiol 2016;217:177-181 https://doi.org/10.1016/.ijfoodmicro.2015.10.028

Pitcher GC, Figueiras FG, Hickey BM, Moita MT. The physical oceanography of upwelling system nd the development of harmful algal blooms. Prog Oceanogr 2010;85(1-2):5-32. https://doi.org/10.1016/ pocean. 2010.02 .002

Reddy P, Naidoo RN, Robins TG, et al. GSTM1 and GSTP1 gene variants and the effect of air pollutants on lung function measures in South African children. Am J Ind Med 2012;55(12):1078-1086. https://doi. org/10.1002/ajim.22012

Röllin HB, Odland JØ, Sandanger TM. The environmental health and contaminants in South Africa. Toxicol Lett 2010;196(Suppl):S327. https://doi.org/10.1016/j.toxlet.2010.03.1032

Rong Y, Luo X, Zhang Z, Cui X, Liu Y, Chen W. Occupational exposure to asbestos and cardiovascular related diseases: A meta-analysis. Prev Med Rep 2015;2:920-926. https://doi.org/10.1016/j. pmedr.2015.10.005

Rother HA. South African farm workers' interpretation of risk assessment data expressed as pictograms on Rother HA. South African farm workers' interpretation of risk assessment data expressed as pister.
pesticide labels. Environ Res 2008;108(3):419-427. https://doi.org/10.1016/j.envres.2008.07.005

Rother HA. Falling through the regulatory cracks: Street selling of pesticides and poisoning mong urban youth in South Africa. Int J Occup Environ Health 2010;16(2):202-213. https://doi. org/10.1179/10773521079916026

Rother HA. Improving poisoning diagnosis and surveillance of street pesticides. S Afr Med 2012;102(6):485-488. https://doi.org/10.7196/samj.5838

Rother HA. Communicating pesticide neurotoxicity research findings and risks to decision-makers and the public. Neurotoxicology 2014;45:327-337. https://doi.org/10.1016/.jneuro.2014.03.001

Rybicki EP, Chikwamba R, Koch M, Rhodes JI, Groenewald J-H. Plant-made therapeutics: An emerging platform in South Africa. Biotechnol Adv 2012;30(2):449-459. https://doi.org/10.1016/j. biotechadv.2011.07.014

Scovronick N, Armstrong B. The impact of housing type on temperature-related mortality in South Africa, 1996 - 2015. Environ Res 2012;113:46-51. https://doi.org/10.1016/j.envres.2012.01.004

Sekhotha MM, Monyeki KD, Sibuyi ME. Exposure to agrochemicals and cardiovascular disease: A review. Int J Environ Res Public Health 2016;13(2):229. https://doi.org/10.3390/ijerph13020229

Semenya S, Potgieter M, Erasmus L. Ethnobotanical survey of medicinal plants used by Bapedi healers to treat diabetes mellitus in the Limpopo Province, South Africa. J Ethnopharmacol 2012;141(1):440-445. https:// doi.org/10.1016/j.jep.2012.03.008

Semenya SS, Potgieter MJ, Erasmus LJC. Indigenous plant species used by Bapedi healers to treat sexually transmitted infections: Their distribution, harvesting, conservation and threats. S Afr J Bot 2013;87:66-75. https://doi.org/10.1016/j.sajb.2013.03.001 
Shackleton CM, Hebinck P, Kaoma H, et al. Low-cost housing developments in South Africa miss the opportunities for household level urban greening. Land Use Policy 2014;36:500-509. https://doi.org/10.1016/j. landusepol.2013.10.002

Shirinde J, Wichmann J, Voyi K. Association between wheeze and selected air pollution sources in an air pollution priority area in South Africa: A cross-sectional study. Environ Health 2014;13(1):32. https:// doi.org/10.1186/1476-069x-13-32

Shirinde J, Wichmann J, Voyi K. Allergic rhinitis, rhinoconjunctivitis and hayfever symptoms among children are associated with frequency of truck traffic near residences: A cross sectional study. Environ Health 2015;14:84. https://doi.org/10.1186/s12940-015-0072-1

Shirinde J, Wichmann J, Voyi K. Environmental tobacco smoke and the risk of eczema symptoms among school children in South Africa: A cross-sectional study. BMJ Open 2015;5(8):e008234. https://doi. org/10.1136/bmjopen-2015-008234

Sibanda T, Selvarajan R, Tekere M. Urban effluent discharges as causes of public and environmental health concerns in South Africa's aquatic milieu. Environ Sci Pollut Res Int 2015;22(23):18301-18317. health concerns in South Africass aquatic
https://doi.org/10.1007/s11356-015-5416-4

Smith MT, Schroenn Goebel J, Blignaut JN. The financial and economic feasibility of rural household biodigesters for poor communities in South Africa. Waste Manage 2014;34(2):352-362. https://doi org/10.1016/j.wasman.2013.10.042

Stoev SD. Foodborne mycotoxicoses, risk assessment and underestimated hazard of masked mycotoxins and joint mycotoxin effects or interaction. Environ Toxicol Pharmacol 2015;39(2):794-809. https://doi org/10.1016/j.etap.2015.01.022

Street RA, Kabera GM, Connolly C. Metallic mercury use by South African traditional health practitio

Takahashi K, Kang SK. Towards elimination of asbestos-related diseases: A theoretical basis for international cooperation. Saf Health Work 2010;1(2):103-106. https://doi.org/10.5491/shaw.2010.1.2.103

Tan SY, Cayabyab BF, Alcantara EP, et al. Comparative binding of CrylAb and CrylF Bacillus thuringiensis toxins to brush border membrane proteins from Ostrinia nubilalis, Ostrinia furnacalis and Diatraea saccharalis (Lepidoptera: Crambidae) midgut tissue. J Invertebr Pathol 2013;114(3):234-240.

Teare J, Kootbodien T, Naicker N, Mathee A. The extent, nature and environmental health implications of cottage industries in Johannesburg, South Africa. Int J Environ Res Public Health 2015;12(2):1894-1901. https://doi.org/10.3390/ijerph120201894

Thabethe ND, Engelbrecht JC, Wright CY, Oosthuizen MA. Human health risks posed by exposure to PM10 for four life stages in a low socio-economic community in South Africa. Pan Afr Med J 2014;18:206. https://doi.org/10.11604/pamj.2014.18.206.3393

Thomas EP, Seager JR, Mathee A. Environmental health challenges in South Africa: Policy lessons from case studies. Health Place 2002;8(4):251-261. https://doi.org/10.1016/s1353-8292(02)00006-0

Van der Merwe M, Hoffman LC, Jooste PJ, Calitz FJ. The hygiene practices of three systems of game meat production in South Africa in terms of animal class and health compliance. Meat Sci 2013;94(1):145152. https://doi.org/10.1016/j.meatsci.2013.01.011

Van der Merwe M, Jooste PJ, Hoffman LC. Application of European standards for health and quality control of game meat on game ranches in South Africa. J S Afr Vet Assoc 2011;82(3):170-175. https://do org/10.4102/jsava.v82i3.6

Van der Merwe M, Jooste PJ, Hoffman LC, Calitz FJ. Two sampling techniques for game meat. J S Afr Vet Assoc 2013;84(1):E1-E6. https://doi.org/10.4102/jsava.v84i1.536
Van der Merwe M, Michel AL. An investigation of the effects of secondary processing on Mycobacterium spp. in naturally infected game meat and organs. J S Afr Vet Assoc 2010;81(3):166-169. https://doi.org/10.4102/ spp. in naturally
jsava.v81i3.141

Van der Walt A, Singh T, Baatjies R, Lopata AL, Jeebhay MF. Work-related allergic respiratory disease and asthma in spice mill workers is associated with inhalant chili pepper and garlic exposures. Occup Environ Med asthma in spice mill workers is associated winh inhalant chili pepper

Van Eeden M, Korsten L. Factors determining use of biological disease control measures by the avocado Van Eeden M, Korsten L. Factors determining use of biological disease control measures
industry in South Africa. Crop Prot 2013;51:7-13. https://doi.org/10.1016/j.cropro.2013.03.011

Van Niekerk L, Adams JB, Bate GC, et al. Country-wide assessment of estuary health: An approach
Vastry in South Africa. Crop Prot 2013:51:7-13. https:/doi.org/10.1016/.cropro.2013.03.011 for integrating pressures and ecosystem response in a data limited environment. Estuar Coast Shelf Sci 2013:130:239-251. https://doi.org/10.1016/j.ecss.2013.05.006

Van Roosbroeck S, Wichmann J, Janssen NAH, et al. Long-term personal exposure to traffic-related air
(1) Van Roosbroeck S, Wichmann J, Janssen NAH, et al. Long-term personal exposure to traffic-related air
bollution among school children, a validation study. Sci Total Environ 2006;368(2-3):565-573. https://doi. pollution among school children,

org/10.1016/j.scitotenv.2006.03.034
Vanker A, Barnett W, Nduru PM, Gie RP, Sly PD, Zar HJ. Home environment and indoor air pollution Vanker A, Barnett W, Nduru PM, Gie RP, Sly PD, Zar HJ. Home environment and indoor air pollution
exposure in an African birth cohort study. Sci Total Environ 2015;536:362-367. https://doi.org/10.1016/j. scitotenv.2015.06.136

Viljoen MJ. Tertiary education requirements in the geosciences for the minerals industry and in the environmental field to meet the demands of the 21st century in South Africa. J Afr Earth Sci 1999;28(4):873838. https://doi.org/10.1016/s0899-5362(99)00061-5

Von Schirnding Y. Health and sustainable development: Can we rise to the challenge? Lancet 2002;360(9333):632-637. https://doi.org/10.1016/s0140-6736(02)09777-5

Von Schirnding YER, Fuggle RF. A study of the distribution of urban environmental lead levels in Cape Town, South Africa. Sci Total Environ 1996;188(1):1-8. https://doi.org/10.1016/0048-9697(96)05122-4

Von Schirnding Y, Mathee A, Kibel M, Robertson P, Strauss N, Blignaut R. A study of pediatric blood lead levels in a lead mining area in South Africa. Environ Res 2003;93(3):259-263. https://doi.org/10.1016/ s0013-9351(03)00117-8

Wolmarans P, Chetty J, Danster-Christians N. Food composition activities in South Africa. Food Chem 2013;140(3):447-450. https://doi.org/10.1016/j.foodchem.2012.10.064

Wright CY, Albers PN, Oosthuizen MA, Phala N. Self-reported sun-related knowledge, attitudes and behaviours among schoolchildren attending South African primary schools. Photodermatol Photoimmunol behaviours among schoolchildren attending South African primary sc

Wright CY, Brogniez C, Ncongwane KP, et al. Sunburn risk among children and outdoor workers in Wright CY, Brogniez C, Ncongwane KP, et al. Sunburn risk among children and outdoor workers in
South Africa and Reunion Island coastal sites. Photochem Photobiol 2013;89(5):1226-1233. https://doi. South Africa and Reu

org/10.1111/php. 12123

Wright CY, Diab R. Air pollution and vulnerability: Solving the puzzle of prioritization. J Environ Health 2011;73(6):56-64.

Wright, CY, Garland, RM, Norval, M, Vogel, C. Human health impacts in changing South African climate. S Afr Med J 2014;104(8):579-582. https://doi.org/10.7196/SAMJ.8603

Wright CY, Mathee A, Garland RM. Climate change, human health and the role of environmental health practitioners. S Afr Med J 2014;104(8):518-519. https://doi.org/10.7196/SAMJ.7994

Wright CY, Mathee A, Oosthuizen MA. Challenging times for environmental health in South Africa: The role of the Environmental Health Research Network. S Afr Med J 2014:104(1):20-21. https://doi. org $10.7196 /$ SAMJ

Wright CY, Norval M, Hertle RW. Oculocutaneous albinism in sub-Saharan Africa: Adverse sunassociated health effects and photoprotection. Photochem Photobiol 2015;91(1):27-32. https://doi. org/10.1111/php. 12359 